|| ISSN(online): 2589-8698 || ISSN(print): 2589-868X || International Journal of Medical and Biomedical Studies

Available Online at www.ijmbs.info

Volume 3, Issue 2; February: 2019; Page No. 54-56

PubMed (National Library of Medicine ID: 101738825)

Index Copernicus Value 2017: 40.03

\title{
TO STUDY KNOWLEDGE, ATTITUDE \& PRACTICES TOWARDS IMMUNIZATION AGAINST HEPATITIS B VIRUS INFECTION AMONGST NURSING STAFF OF M.G. HOSPITAL, BHILWARA
}

\author{
Mahesh Kumar Choudary ${ }^{1}$, Manmohan Gupta ${ }^{2}$, Rachit Saxena ${ }^{3}$, Sandeep Kumar Uppadhaya ${ }^{4}$ \\ ${ }^{1,3,4}$ Assistant Professor, ${ }^{2}$ Associate Professor, \\ ${ }^{1,2,4}$ Department of Community Medicine, RVRS Medical College, Bhilwara \\ ${ }^{3}$ Department of Biochemistry, RVRS Medical College, Bhilwara
}

Article Info: Received 22 January 2019; Accepted 15 February. 2019

Cite this article as: Choudary, M., Gupta, M., Saxena, R., \& Uppadhaya, S. (2019). TO STUDY KNOWLEDGE, ATTITUDE \& PRACTICES TOWARDS IMMUNIZATION AGAINST HEPATITIS B VIRUS INFECTION AMONGST NURSING STAFF OF M.G. HOSPITAL, BHILWARA. International Journal of Medical and Biomedical Studies, 3(2).

DOI: https://doi.org/10.32553/ijmbs.v3i2.95

Address for Correspondence: Dr. Manmohan Gupta, Associate Professor, Department of Community Medicine, RVRS Medical College, Bhilwara

Conflict of interest: No conflict of interest.

\section{Abstract}

Background: Hepatitis B virus (HBV) is a double-stranded circular DNA virus and member of the Hepadnaviridae family of viruses.

Methods:This cross sectional study was done on 250 nursing staff. There were total 263 nursing staff in this hospital out of which 250 enrolled voluntarily to participate in this study. The objective, nature and benefits of this study were explained and informed \& written consent was taken from all participants. All nursing staff was interviewed structured self-completed quaternaries.

Results: Hepatitis B virus (HBV) infection is an occupational health hazard preventable by vaccination. $78 \%$ of nursing staff know that Hep B is a vaccine preventable. $42 \%$ of participants knew that getting vaccinated offers a protection from infection for 15 years. $16 \%$ of nursing staff are aware that a titre value of more than $10 \mathrm{ml} \mathrm{U} / \mathrm{ml}$ is needed for protection from Hepatitis B infection. $84 \%$ of nursing staff are willing to motivate others and encourage them to get vaccinated against Hepatitis $B$.

Conclusion: This study highlighted the need to have nursing staff educated regarding significance of immunization against vaccine preventable disease.

Keywords: Hepatitis, Immunization, Liver

\section{Introduction:}

Hepatitis B virus (HBV) is a double-stranded circular DNA virus and member of the Hepadnaviridae family of viruses. ${ }^{1}$

Hepatitis B is an important cause of inflammation of the liver that is potentially life threatening as well as preventable. According to World Health Organization, 7.8 million people die each year from hepatitis B infection globally and another 240 million people are chronically infected (defined as positive HBsAg for minimum 6 months) ${ }^{2}$. Nonetheless it's an important occupational hazard for health care professionals. However, through vaccination and safety measures, it can be prevented successfully. Bangladesh is in intermediate zone of prevalence of hepatitis $B$ infection and the 
lifetime risk of acquisition of hepatitis $B$ in these areas is 20 to $60 \%^{3}$. In one study the prevalence of hepatitis $B$ in Bangladeshi general population was $5.4 \%$ with a male predominance 3 . Vertical transmission, transmission through unsafe sex, unsafe injections and body fluid like blood remains the most common route of infection for hepatitis $B$ virus ${ }^{4}$. Health-care workers have the highest occupational risk for hepatitits B infection.

\section{Materials and Methods}

This cross sectional study was done on 250 nursing staff. There were total 263 nursing staff in this hospital out of which 250 enrolled voluntarily to participate in this study. The objective, nature and benefits of this study were explained and informed written consent was taken from all participants. All nursing staff were interviewed structured self-completed quaternaries.

\section{Results}

A total of 250 nursing staff responded to the questionnaire, $76 \%$ were female, and $24 \%$ were male.

Table 1: Descriptive characteristics of the participants

\begin{tabular}{|l|l|l|}
\hline Characteristics & No. of participants & Percentage \\
\hline Sex & & \\
\hline Male & 60 & $24 \%$ \\
\hline Female & 190 & $76 \%$ \\
\hline Marital status & & \\
\hline Married & 220 & $88 \%$ \\
\hline Unmarried & 30 & $12 \%$ \\
\hline
\end{tabular}

Hepatitis B virus (HBV) infection is an occupational health hazard preventable by vaccination. $78 \%$ of nursing staff know that Hep $B$ is vaccine preventable.

$42 \%$ of participants knew that getting vaccinated offers a protection from infection for 15 years. $16 \%$ of nursing staff are aware that a titre value of more than $10 \mathrm{ml} \mathrm{U} / \mathrm{ml}$ is needed for protection from Hepatitis B infection. $84 \%$ of nursing staff are willing to motivate others and encourage them to get vaccinated against Hepatitis B.

\section{Discussion}

Hepatitis B virus (HBV) infection is an occupational risk for health care professionals especially in developing countries which have a carrier rate of about 4\%. Every year HBV infection accounts for 1.1 million cases. As such, incidence of HBV infection can only be brought down by giving proper education regarding its transmission and also getting nursing students immunized with Hepatitis $B$ vaccine. The number of students getting immunized showed an increase due to awareness created to them during their medical curriculum.

The present study concludes that there is an increased awareness among nursing students regarding the need to be vaccinated against Hepatitis B. However all the students were not vaccinated against Hepatitis $B$, which make them vulnerable to the disease. The reason as to why vaccination was not taken by few students needs to be addressed and make them realise the importance of vaccination. Since nursing students are at increased risk of acquiring needle stick injury, and also due to increased prevalence rate of Hepatitis B in India, nursing students should mandatorily be vaccinated upon entry into the nursing college. It is recommended that a policy be in place for complete vaccination and health education of all nursing students upon enrolling into nursing course. It's also important to routinely check antibody titre and if its below $10 \mathrm{ml} \mathrm{U} / \mathrm{ml}$ a booster dose be advised. 
Dr. Manmohan Gupta et al, International Journal of Medical and Biomedical Studies (IJMBS)

\section{Conclusion}

This study highlighted the need to have nursing staff educated regarding significance of immunization against vaccine preventable disease.

\section{References}

1. Park J.E., Park K. - Text Book of Preventive and Social Medicine, 19th Edition, M.S. Banarsidas. Bhanot, Jabalpur. 267, 2007.
2. World Health Organization. Hepatitis B Fact sheets. Reviewed july 2017. http:// www.who.int/mediacentre/factsheets/fs204 /en/

3. Malik A.H., Lee W.M. - Chronic Hepatitis B Virus Infection. Treatment Strategies for the next Millenium. Annals of Internal Medicine. Volume 132 (9):723-731, May 2000.

4. Tandon B.N., Acharaya S.K., Tandon A.Epidemiology of Hepatitis $B$ virus infection in India. Gut. 38(2):56-59, 1996. 